\title{
Public safety intelligence activity: Advice in the fight against criminal organizations
}

\author{
Atividade de inteligência em segurança pública: $\mathrm{O}$ assessoramento no combate às organizações \\ criminosas \\ Actividad de inteligencia de seguridad pública: Asesoramiento en la lucha contra organizaciones \\ criminales
}

Received: 07/15/2021 | Reviewed: 07/19/2021 | Accept: 07/20/2021 | Published: 07/28/2021

\author{
Herick Wendell Antônio José Gomes \\ ORCID: https://orcid.org/0000-0001-6975-3877 \\ Polícia Militar do Estado do Pará, Brazil \\ E-mail: herickwendell@gmail.com \\ Roberto Magno Reis Netto \\ ORCID: https://orcid.org/0000-0002-5076-6149 \\ Universidade Federal do Pará, Brazil \\ Faculdade da Amazônia, Brazil \\ E-mail: bob_reis_ufpa@yahoo.com.br \\ Clay Anderson Nunes Chagas \\ ORCID: https://orcid.org/0000-0002-4223-0192 \\ Universidade do Estado do Pará, Brazil \\ Universidade Federal do Pará, Brazil \\ E-mail: claychagas@ufpa.br \\ Wando Dias Miranda \\ ORCID: https://orcid.org/0000-0003-1630-6736 \\ Faculdade da Amazônia, Brazil \\ E-mail: claychagas@ufpa.br
}

\begin{abstract}
The present work, as a research involving the intelligence activity in Public Security, the present work aimed, through a historical rescue, which dates back to the emergence of a criminal organization in the state of Pará - Brazil, to verify how the intelligence activity it is capable of advising the decision-making process of public security institutions, in order to generate a balance of forces favorable to the latter, in the fight against crime. It started from the hypothesis that the intelligence agencies would show themselves capable of gathering privileged information, according to legality and efficiency criteria, able to subsidize the decision-making process. Using an inductive method and a qualitative documentary analysis, it was identified that, in addition to subsidizing managers with appropriate knowledge, the agencies were responsible for the frustration of measures of direct confrontation with the State, preventing damage to public coffers, as well as unjust attacks on civil and military civil servants and the Pará society itself.
\end{abstract}

Keywords: Intelligence activity; Organized criminal groups; Public security.

\section{Resumo}

O presente trabalho, enquanto pesquisa envolvendo a atividade de inteligência em Segurança Pública, o presente trabalho objetivou, por meio de um resgate histórico, que remota ao surgimento de uma organização criminosa no estado do Pará - Brasil, verificar de que forma a atividade de inteligência é capaz de assessorar o processo decisório das instituições de segurança pública, de modo a gerar um equilíbrio de forças favorável a esses últimos, no combate ao crime. Partiu-se da hipótese de que os órgãos de inteligência se mostrariam capazes de levantar informações privilegiadas, de acordo com critérios de legalidade e eficiência, aptas a subsidiar o processo decisório. Sob um método indutivo e uma análise documental qualitativa, identificou-se que, além de subsidiar os gestores com conhecimentos apropriados, as agências foram responsáveis pela frustração de medidas de enfrentamento direto ao Estado, evitando danos aos cofres públicos, bem como, injustas agressões a servidores públicos civis e militares e à própria sociedade paraense.

Palavras-chave: Atividade de inteligência; Facções criminosas; Segurança pública.

\section{Resumen}

El presente trabajo, como una investigación que involucra la actividad de inteligencia en Seguridad Pública, el presente trabajo tuvo como objetivo, a través de un rescate histórico, que se remonta al surgimiento de una organización criminal en el estado de Pará - Brasil, para verificar cómo la actividad de inteligencia es capaz de asesorar el proceso de toma de decisiones de las instituciones de seguridad pública, a fin de generar un equilibrio de 
fuerzas favorable a estas últimas, en la lucha contra la delincuencia. Partió de la hipótesis de que las agencias de inteligencia se mostrarían capaces de recabar información privilegiada, según criterios de legalidad y eficiencia, capaces de subsidiar el proceso de toma de decisiones. Mediante un método inductivo y un análisis documental cualitativo, se identificó que, además de subsidiar a los gerentes con los conocimientos adecuados, los organismos eran responsables de la frustración de las medidas de enfrentamiento directo con el Estado, previniendo daños a las arcas públicas, así como injustas. ataques a funcionarios civiles y militares ya la propia sociedad de Pará.

Palabras clave: Actividad de inteligência; Facciones criminales; Seguridad pública.

\section{Introduction}

The present work deigns to make a pragmatic analysis of the so-called intelligence activity in public security (DNISP, 2014). Much is said about the importance of intelligence activities, as well as about the essentiality of the organs dedicated to this function. However, little is yet proven or debated about how the activity can, in fact, generate an imbalance in territorial power relations (Raffestin, 1993) between the Democratic State of Law and other social agents, especially those of crime organized.

Therefore, this study aims, through a historical rescue dating back to the emergence of a criminal organization in the state of Pará - Brazil, to verify how intelligence activity is able to council the decision-making process of public security institutions, in order to generate a balance of forces favorable to the latter, in the fight against crime (notably, criminal factions). The tone study or based on the monitoring of the emergence and the transformations of the faction called Comando Clase A - CCA (331), between 2015 and 2017, from Altamira-PA, starring public security intelligence agencies in the State of Pará, Brazil.

The importance of the discussion resided, in first place, in the need to verify theoretical postulations indicating the importance of intelligence activity, still very relegated to the background strategic in scientific circles of security and defense as well as in the sciences in general. In addition, the study shows how a set of specialized actions, aimed at advising the decision-making process of public authorities, can be of considerable importance in the battle against crime, especially organized crime. In this sense, the historical upheaval of the appearance and development of the faction highlights specific moments in which its monitoring was essential to the achievement of sensitive knowledge, crucial to the decision-making process.

Furthermore, we sought to demonstrate how intelligence activity represents an important public policy, which, ultimately, is linked to the State's duty to guarantee public security, being inherent, therefore, in the very idea of human dignity of all territorial agents (antagonist or not) subject to the tutelage of the Brazilian Democratic State.

From the outset, the inherent importance of the balance generated by the performance of State Intelligence Agencies for strategic purposes should be mentioned. As the State is the commanding agent of the territory, par excellence, doing it according to the purposes inherent to democratic principles and inherent legal plans, it is up to the security agencies to seek the maximum predictability inherent to the action of adverse territorial agents, as well as facts influencing the implementation of security policies.

This predictability, of course, is in line with the strategic purposes of less energy expenditure in state action (Raffestin, 1993) and, in particular, contributing to the reduction of uncertainty inherent to the actions and operations (Protásio, 2011) carried out by the agencies of public safety.

\section{Methodology}

The study adopted the inductive method. According to Lakatos and Marconi (2003), this method is characterized by collecting particular data that, carefully analyzed, can reflect generalizable conclusions, therefore, applicable to other contexts.

The choice was made considering intelligence activity a true public policy of the State, whose importance and 
advisory capacity can be felt in each effective action, in order to generate balances favorable to the State, in its power relations with other territorial agents. Thus, proving this assertive theory in practice, in addition to confirming the scientific postulates about the activity, it will clarify the relevance of this activity for the scientific circles and security agencies, as well as for society in general.

The inductive method allowed, in this sense, the evaluation of the concrete use of the intelligence activity as a state power trump in a concrete case (particular aspect), which can be universalized to other similar cases. In other words, it is demonstrated, from one case, how intelligence activity can generate a balance of forces in favor of the State, in a perspective applicable to other cases (universal aspect) (Pereira et al, 2018). It was understood, from Raffestin (1993), that the greater the level of information held by a territorial agent, the less energy will be spent by the agent to materialize their power plans, which is a valid perspective for the state, as territorial agent par excellence.

In practice, the study stuck to the content of a social fact that occurred in the state of Pará, Brazil, between 2015 and 2017: the historical process of emergence and development of a criminal faction, the Comando Clase A - CCA (331), and its monitoring by a public security intelligence agency.

Therefore, an instrumental case study was carried out, understood by Alvez-Mazzotti (2006), Reis Netto and Chagas (2019a) as a process of analysis of a set of social facts linked to a phenomenon interesting to science (in this case, the emergence and monitoring of the highlighted faction), through which, it is possible to draw a set of conclusions about the likelihood of a theory in relation to reality, or the need for its adaptation or conformation, according to the objective listed by a scientific study.

As data collection techniques, the study used: a) the experience report of the first researcher, who, as a military police officer who has already been assigned to areas in which the faction has registered activities, in addition to having participated in actions of survey of information about the same, and who has already held positions linked to the intelligence agency in public security that had direct contact with the faction under study; b) documentary research based on two kinds of primary sources: b.1) Personal diary with notes prepared by the first researcher, throughout his professional performance as a public agent directly involved in intelligence activities; b.2) unclassified documents (reports, yearbooks, etc.) of the institutional security advisory in question, which, therefore, have the quality of open data, being fully usable without any legal complications; c) the theoretical and practical experience of other researchers, on issues related to criminal factions, intelligence activities and public security.

For data analysis, the information collected during intelligence activities was duly organized in a historical line, precisely, for the purpose of exposing the process of emergence of the faction and its respective development, based on information collected by the highlighted intelligence agency. The approach, therefore, was qualitative (Lakatos \& Marconi, 2003).

Then, the information was correlated to the actions of the public security agencies, as a way to highlight how their actions became more effective, based on sensitive and current knowledge, produced by the highlighted intelligence agency, precisely with to the achievement of the general objective of the study, analyzing how that knowledge balanced the difficult antagonistic relationship between the Democratic Rule of Law and the criminal organization, in a favorable way to the former.

Names and records of those involved in that faction were omitted (which will be identified only by acronyms such as: L - leadership, C - Collaborator, F - faction member), in respect of their constitutional right to forget them, as well as, because they are not the focus of the study, if not, the phenomenon of the emergence and development of the faction and its monitoring by the intelligence agencies in public security, with special attention to the fact that the performance of the latter provided a rebalancing of forces in the scenario of Pará.

Regarding this last point, in fact, it should be noted that the analysis will highlight how the intelligence agencies 
contributed, through sensitive knowledge, to the strategic decision-making process by the public security agencies, without, however, mentioning the operational intelligence techniques (TOI's) employed for this purpose. This measure aims to preserve secrecy regarding the ways in which the intelligence obtains sensitive information capable of generating balance in territorial disputes with criminal organizations, as well as to avoid risks to agents of any kind involved in the processes of searching for data in question. Knowledge obtained will be highlighted and, from this, how the backstage of the history of the studied faction was influenced through knowledge permeated by intelligence agencies.

\section{Theorical Reference}

\subsection{Initial definitions about the intelligence activity}

Gonçalves (2009) prescribes the intelligence activity as a product, organization and as a process. First, as a product, "intelligence represents knowledge produced from a specific cycle, with specialized methodologies [...], which transform information collected into "[...] knowledge sensitive to the decision-making process" (Gonçalves, 2009).

Therefore, as an organization, intelligence represents a set of public agencies and agents (or private, public sector collaborators), which act in the collection of information and transformation into knowledge (Gonçalves, 2009). In simple lines, it is about the intelligence agencies and their respective agents, in Brazil, created in accordance with the law n. 9,883/99 - which institutes the Brazilian intelligence system (Brasil, 1999), and, in the scope of the state of Pará, according to law nr. 7,584/11 - establishing the security intelligence subsystem of the state of Pará (Estado do Pará, 2011).

Finally, Gonçalves (2009) defines intelligence activity, under a procedural aspect, as a set of means and actions by which the meeting process takes place (by collecting or searching for open or denied data), analysis and dissemination of knowledge, under its own methodologies, with the fulcrum of advising authorities in the decision-making process.

Antunes (2001, p. 19) states that "intelligence activity refers to certain types of information, related to the security of the State, to the activities performed in order to obtain it [...]" (the activity of intelligence, per se) or "[...] prevent other countries from obtaining it and the organizations responsible for carrying out and coordinating the activity in the state sphere". It is a fundamental activity for the preservation of the state structure and public institutions. It is precisely under this material aspect that the present analysis will focus more intensely on the so-called intelligence activity, precisely, expressing agreement with its direct destination for state advisory services.

From a legal point of view, Reis Netto et al (2018) define the intelligence activity as a true public policy necessary for the maintenance of the Democratic Rule of Law, which, as such, is carried out as a set of political actions, subject to politicallegislative controls (Miranda, 2018), or, in a set of administrative acts, subject to common legal control mechanisms, with some peculiarities (Nascimento et al, 2018). In fact, in democratic times, information is a true asset necessary for the very subsistence of the origin and a guarantee of a balance so that citizens, individually or in groups, can exercise their freedoms, through a society that provides them legal and material security for this purpose.

In the sphere of public security, the so-called public security intelligence activity is defined in the national doctrine of public security intelligence - DNISP as:

[...] the permanent and systematic exercise of specialized actions to identify, assess and monitor real or potential threats in the sphere of Public Security, basically oriented towards the production and safeguarding of knowledge necessary to support decision makers, for planning and execution of a Public Security policy and actions to prevent, prevent, neutralize and repress criminal acts of any nature that affect public order, the safety of people and property (Brazil, 2014, p. 13).

At the same time, this document defines the purposes of this activity in the field of Brazilian public security, a notion 
that applies to any sphere in which the activity is exercised by the public authorities:

\subsection{PURPOSES}

1.2.1 Provide diagnoses and forecasts on the evolution of situations in the interest of Public Security, supporting its users in the decision-making process. 1.2.2 Contribute so that the interactive process between users and Intelligence professionals produces cumulative effects, increasing the level of efficiency of these users and their respective organizations.

1.2.3 Subsidize the integrated strategic planning of the Public Security system and the preparation of specific plans for the various organizations that comprise it.

1.2.4 Advise, with relevant information, prevention and repression operations, in the interest of Public Security.

1.2.5 Safeguard ISP knowledge production. (Brazil, 2014, p. 13).

Specifically, with regard to items 1.2.3 and 1.2.4 outlined above, the public security intelligence activity aimes at providing sensitive knowledge to the planning of public security agencies, in the short, medium and long term, and, as the objectives to be achieved or agents to be faced in the context of each territory become more complex, the intelligence activity starts to obtain more strategic contours, as shown in the literature (Gonçalves, 2009; Antunes, 2001).

\subsection{Intelligence, strategy and territorial disputes}

The strategic character of intelligence activity comes precisely from the relationship pointed out by Raffestin (1993) in relation to the idea of state hegemony: despite the State being considered the territorial agent par excellence, there are several other agents that act concurrently with it, in search of the domain of the multiple territories that are constituted over the space, often acting in an antagonistic way to the space (and its respective organs).

When this concept is brought to the perspective of public safety, it occurs that subject manifestations committed to the exercise of various criminal procedures laid down by law, constitute Exem poles of antagonistic regional stakeholders to the State, which, in turn, it will be up to the expenditure of energy and resources (Raffestin, 1993) to prevent, understand and reprimand crime.

However, when talking about the expenditure of energy and resources, in practical terms one is talking about expenditure of physical and mental strength of security agents, as well as resources from the treasury, which obviously requires an optimization of the application of those assets in compliance with the constitutional principle of efficiency (Brazil, 1988). According to Raffestin (1993), this makes it essential to obtain a greater set of information, prior to action, so that the inversely proportional relationship between information/energy is balanced, meaning a better use of the forces inherent to the security organs. In fact, knowing how to act lessens the expenditure of strength for action.

It is in this desideratum that the intelligence activity represents a real power trump (Raffestin, 1993) to the State. As a set of bodies imbued with the specialized exercise of collecting information, subjecting them to a cycle that transforms them into current and sensitive knowledge, the intelligence activity is suitable (provided it is correctly applied, as a public policy) to provide authorities with decision-making power from reliable, timely and secure information to the adoption of more efficient planning and strategies, providing less energy expenditure.

That is why, for a long time, the literature on intelligence points to this fundamental character of the activity of intelligence. Keegan (2006), for example, informs that the intelligence activity can generate real power imbalances throughout the stories of the confrontations, since, obviously, it guarantees safe and fast information to the decision-making process. In the same sense, Cepik (2001) informs that the intelligence activity is of fundamental importance to the knowledge and confrontation of antagonistic agents to the State, whether in an internal or external sphere, precisely because of its capacity to gather strategic and temporally valid information, which, again, is confirmed by authors such as Farias (2017). Intelligence, therefore, is essential to maintaining order. 
And, it is precisely around these assertions that the present study intends its development: In simple lines, the objective outlined here is aimed at verifying how the intelligence activity enabled an effective confrontation of the highlighted faction, in the analyzed time period, from knowledge produced by a specific security agency, generating a balance of forces favorable to the State, by its security organs, in the preservation of the inescapable purpose of the public power: the order and safeguarding of public interests (Fernandes, 2014).

\section{Results and discussions}

\subsection{Timeline: Comando Clase A}

The criminal organization named Comando Clase A (CCA - 331), became known worldwide on July 29, 2019, when its members, people deprived of liberty serving time at the Regional Recovery Center of Altamira - CRRALT, in the state of Pará, led to the death of 58 (fifty-eight) inmates of a rival faction, the Comando Vermelho, after invading the prison block destined for members of the latter faction. Also, on 07.31.2019, when CCA prisoners were transferred to other prisons in the metropolitan region of Belém-PA, the death of another 4 (four) inmates was recorded, by mechanical asphyxia, within an official transport of the Secretariat of Penitentiary Administration of Pará (G1, 2019). In all, 62 (sixty-two) were killed.

The episode, publicly known as the Altamira Massacre (G1, 2019), was recognized as one of the most violent in the country, being the second highest murder recorded in a federation prison, trailing only in terms of death toll. also known worldwide massacre of Carandiru. However, the genesis of the Comando Clase A criminal organization (CCA - 331) dates back to 2015, linked to a series of social and geopolitical factors that (even more) integrated the territory of Pará into drug trafficking routes. With the advent of the Belo Monte Hydroelectric Unit, in the municipalities of Vitória do Xingu-PA and Altamira-PA, in addition to a vertiginous population increase, the region went through a process of formation of precarious areas without an effective state presence (Reis; Souza, 2016), which contributed to the resurgence of various criminal modalities, including drug trafficking.

Inserted as a dot on the national map of drug trafficking, the area soon caught the attention of nationwide factions, which sought to establish alliances with local criminal groups, as a way to control local and regional businesses, as well as, a way to promote its greater representation in a drug flow network throughout the national territory. This time, in alliance with the Primeiro Comando da Capital (PCC - 1533, First Command of the Capital) 3, and under the Command of its first leadership (L1), the Comando Clase A emerged in the municipality of Altamira-PA, taking advantage of the context of state absence, as is typical of the performance of drug trafficking organizations (Reis Netto \& Chagas, 2018), expanding - in local neighborhoods and especially within inland prisons.

This intra-prison expansion, in fact, took place precisely through transfers carried out between different prisons, which allowed an ideological preaching of the principles of organization and co-option of new inmates (Reis Netto \& Chagas, 2019c) for its staff, in a progressive manner. With this, the faction managed to expand into several prisons in the west and southwest regions of Pará, and then reaching all regions, including the Metropolitan Region of Belém-PA. The Comando Clase A, from then onwards, started to gain strength, to the point of consolidating itself outside the walls and relating (expansion of the territorial network) with other local criminal organizations, notably, the Rex Team and the Real Team, establishing commercial relationships involving, in addition to drug trafficking, the purchase of firearms and aid in criminal activities. The faction even tried to co-opt a criminal group based in the district of Águas Lindas, in Ananindeua-PA, metropolitan region, allied with Comando Vermelho, between December 2015 and January 2016 (Reis Netto \& Chagas, 2019a), as found in an investigation official.

And, given the consolidation of certain levels of power, this faction started to adopt measures to confront the public power (Reis Netto \& Chagas, 2019b), leading investments in favor of the release of some of its main leaders (L2 and L3), the 
first, on 11.12.2015, publicly recorded as a result of the death of civilians who transited the proximities of the Penitentiary Complex "Americano", in Santa Izabel do Pará-PA (G1, 2015), and the second, on 02.29.2016, which resulted in the death of a member of the faction $(\mathrm{G} 1,2016 \mathrm{~b})$.

After these events, the action of security agencies managed to arrest two participants of this second action C1 (woman of L2) and C2 (brother of C1) in Castanhal, with artifacts that proved their participation in the unsuccessful attempt (Campo Grande News, 2016).

Later, on 06.04.2016, a joint attack by the Civil Police of the states of Pará and Mato Grosso do Sul, resulted in the death of L1, after he resisted arrest and confronted the police in Campo Grande-MS (Campo Grandes News, 2016). At the time, two other members were arrested (F1 and F2), the first a fugitive from the Pará penal system. From this moment on, the faction went through a process of loss of power, which, however, did not lead to its disappearance or takeover, precisely due to the return of its alliance with the Primeiro Comando da Capital (PCC - 1533, First Command of the Capital), temporarily undone.

However, as the regional and local action of the factions is directly linked to that of their respective allies, at the national level, there is a rupture, in the latter sphere, of a historic alliance between the Comando Vermelho (CV) and the Primeiro Comando da Capital (PCC - 1533, First Command of the Capital), after the latter took control of the so-called Rota Caipira of trafficking - which connects the country's mid-west to the southeast and south (Manso \& Dias, 2018), generated direct repercussions in terms of factions of the State of Pará, including, for the CCA (ally of the PCC).

Thus, since the first half of 2016, the two nationwide factions mentioned have started to dispute processes by factions in Pará prisons, which, with the outbreak of war between them (Manso \& Dias, 2018), forced the need for mass transfers of inmates and the reorganization of prisons according to a geography of criminal factions (Reis Netto \& Chagas, 2019a). This was the context observed in relation to factions throughout 2017 and 2018, when they still carried out measures of direct confrontation with the State and confrontations among themselves, without greater expression in this state of Pará.

The faction under study, the Comando Clase A (CCA -331) as an ally of the Primeiro Comando da Capital (PCC 1533, First Command of the Capital), remained under relative inertia, acting under its command, until, finally, there was an opportunity to attack the members of the Comando Vermelho, its rival, was the protagonist in the murder reported at the beginning of this topic, making its existence and representation known to the public.

\subsection{Intelligence services in public safety and monitoring to factions: In search of strategic advantages}

According to Keegan (2006) and Cepik (2001), it can be said that one of the main characteristics inherent to the performance of intelligence agencies is secrecy. It is essential for intelligence agencies to be able to have a network for the collection of sensitive information in continuous operation in the various spheres of society, without this posing unnecessary risks to the agents involved, as well as, without suspicions about their actions and operations generate interruptions in information flows. It guarantees and, thus, a continuous collection of data capable of generating knowledge relevant to the decision-making process (Brazil, 2014).

Secrecy is also justified in view of the current situation of criminal organizations in Brazil and in the world, which started to generate specialized cells for internal functions (accounting, law, etc.) (Manso \& Dias, 2018), among which, obviously, there is also the cooptation of public and private agents to act in their favor (Reis Netto \& Chagas, 2018) and the deployment of cells that also exercise functions of capturing interesting information to the world of crime, in the image and likeness of agencies of intelligence (Reis Netto \& Chagas, 2019a). Secrecy, therefore, is strategic to the State, since it is also observed by antagonistic criminal organizations. 
As a result, it is common in the history of criminal factions to report their rise and deeds, without, however, highlighting the actions for the rule of law (especially by the security organs) in order to moderate their performance, precisely because the very documents that represent the performance of intelligence agencies end up being subject to more restricted means of access. Precisely for this reason, the moments that many authors point to as momentary success stories of the factions on society, in fact, represent isolated victories in a battle in which the State was already silently climbing several other victories in order to prevent harmful actions to the public order and safety. This is the main point of discussion of these results.

Considering the above history, and revealing the silenced part in relation to the history of the Comando Clase A (CCA - 331) in the official press and common knowledge, this paper took it for granted that knowledge obtained by the intelligence agencies was fundamental; it was good for curbing the advance of this faction, as well as preventing tragedies far greater than the one that brought the organization a spotlight. Furthermore, it demonstrates how the knowledge produced generated a strategic advantage for the State, in an unfavorable context, in which local security forces fight an international drug trafficking network, which co-opts and rearranges national, regional and local criminality, generating, therefore, an imbalance of forces in the respective territorial disputes. The greater the set of information obtained, of course, the lesser will be the effort of security agencies in confronting modern crime, that is, the lesser the expenditure of energy (Raffestin, 1993) - and, consequently, of public resources and human effort.

Furthermore, it must be said that this article inevitably ends up revealing a part of the secret inherent in the performance of intelligence agencies in public security, which, however, was fundamental for the scientifically demonstrating the relevance of intelligence and the strategic nature of its performance, so that the debate can be disseminated in academic and security management circles. However, an important previous methodological contribution is recalled: nothing will be mentioned about the used techniques or the participating agents, precisely so that the essence of the activity itself is not harmed. The focus, in the end, is to denote the strategic importance of intelligence services in public security.

In this sense, it should be noted that the criminal faction in question, despite its origin in 2015, as a criminal group, was only identified after mentions evidenced in investigations of crimes that occurred within the prison, through the use of cell phones and other means of communication commonly handled by criminal factions (Reis Netto \& Chagas, 2018). With this, the intelligence subsystem of the state of Para started a series of operations that, later on, allowed the identification of the main leadership (L1) of the CCA, as well as its genesis in the municipality of Altamira-PA. At the same time, the information allowed the verification of the faction's expansion in several municipalities in the state of Pará, based on the movement of inmates who propagated their adhesion to the criminal organization (Figure 1).

Such information provided the safe haven of sensitive knowledge that, immediately, allowed the visualization of the strategic character of the region for drug trafficking and the understanding of the influential variables regarding the high crime rates that the area started to present since 2014 (Reis \& Souza, 2016). Immediately, measures to improve the actions of public security agencies began to be carried out, especially in the city of Altamira-PA, such as the installation of monitoring cameras in the city (G1 Pará, 2016), for example. 
Figure 1 - Expansion of the CCA's network territory (331), in the territory of Pará, between 2015 and 2017.

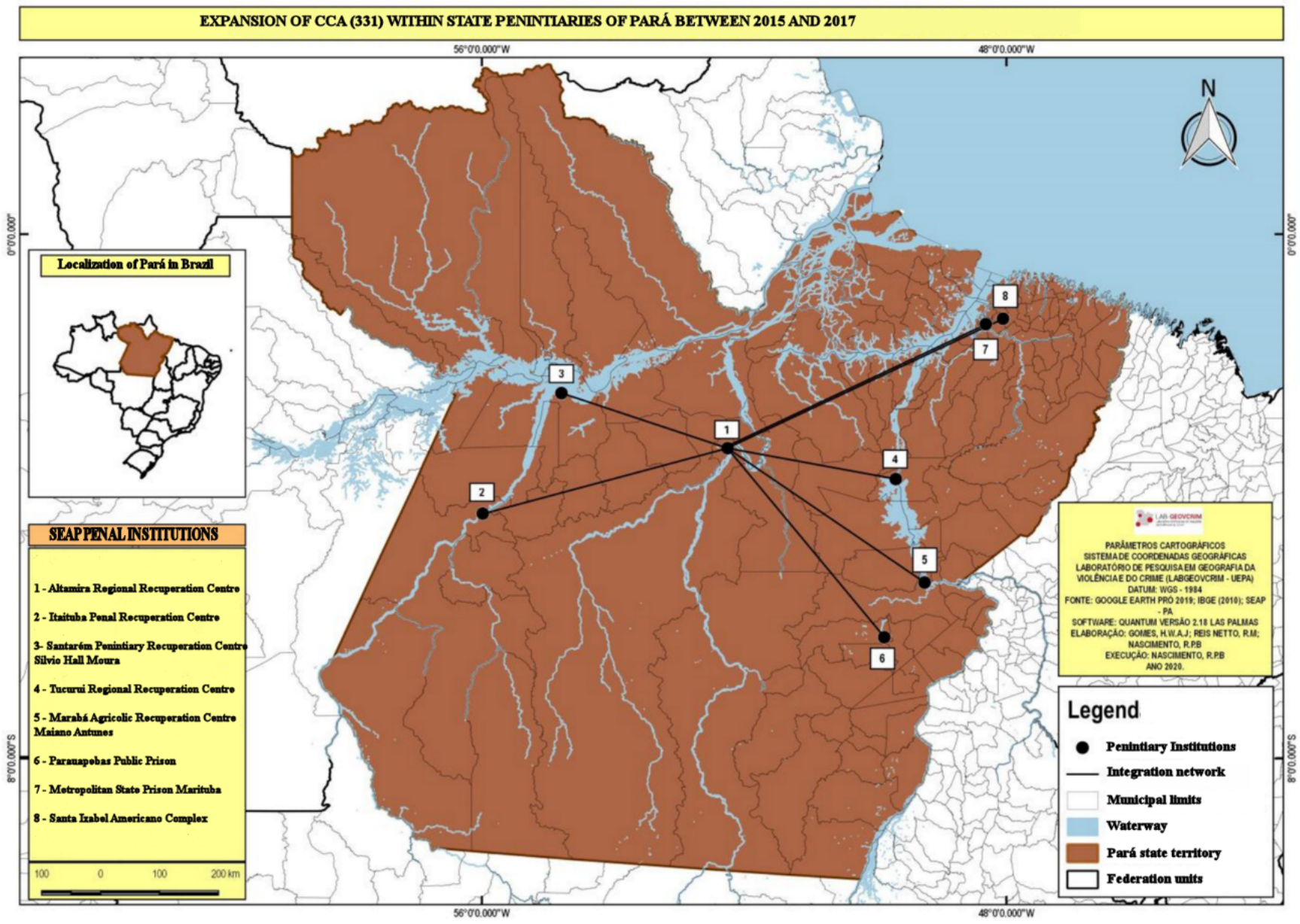

Source: Research data.

As shown in the content of Figure 1, in addition to the genesis in the city of Altamira-PA and the expansion to other municipalities, the information allowed us to identify the penitentiary complexes in which there was the presence of Comando Classe A, as stated, making possible to monitor the actions of its members, avoiding direct confrontations with other groups and allowing the identification of their territorial networks in each city.

In addition to identifying the main leadership (L1) of the faction, the gathering of information provided the knowledge that it had joined efforts with the nationwide faction, the Primeiro Comando da Capital (PCC - 1533, First Command of the Capital), which, unsuspectedly, allowed for an effective investigation enabling the possible territorial network of the faction in question, expanding the spectrum of monitoring the development of the criminal organization.

Also, the widespread use of cell phones was identified as the main means of information flow between the organization's members, in addition to the networks built from transfers historically recorded between the members of the faction, which was determinant for measures of coping with the problem (use of signal blockers, constant magazines, among others) carried out by the then Superintendence of the Penitentiary System of the State of Pará, at the time.

In addition to the relationship with the Primeiro Comando da Capital (PCC - 1533, First Command of the Capital), the links resulting from the still existing national alliance with the Comando Vermelho were verified, which, however, did not represent a peaceful and non-conflictual coexistence in Pará. It was found that the CCA faction incorporated members of the criminal organization of the metropolitan region of Belém, studied to by Netto and Chagas Reis (2019b) in a particular job, and until then, together with the Red Command, that only failed to materialize because of the outbreak of an operation that arrested 
most members of the local territorial group. In fact, the exchange of information between the agencies of the state intelligence subsystem was fundamental for the operation and continuity of the CCA's monitoring measures.

The broadening of the organization's monitoring spectrum, by intelligence and public security agencies was, in fact, crucial to the prior identification of the attempt to rescue two faction leaders (L2 and L3), at the Pará I Penitentiary Recovery Center - CRPP I, in Santa Izabel do Pará, on 02.29.2016 (mentioned in the previous topic), with rapid displacement and organization of police personnel on site, which avoided the repetition of events harmful to public order and safety, as occurred on 12.11.2015. That is, the anticipation of the agencies in relation to the event, provided by the intelligence agencies, allowed the organization of the resources for confrontation by the State, giving it territorial advantage in the conflict that took place and an adequate use of force.

Likewise, the performance of the intelligence agencies allowed the verification of facts and evidence that led to the identification and arrest of C1 (L1's wife) and C2 (L1's brother) as collaborators in the rescue attempt. In possession of them, plates of stolen vehicles, ammunition, cell phones and documents (original and false) of the leaders who would be rescued were found. The arrest in question would never have been possible without prior intelligence work that put managers in conditions of correct performance and, thus, obtain a power trump (knowledge), dealt with in the following paragraph.

From the arrest of $\mathrm{C} 1$ and $\mathrm{C} 2$, the continued survey of relevant information allowed the location of the $\mathrm{L} 1$ leader in Campo Grande-MS (CAMPO GRANDE NEWS, 2016). What was not disclosed is that the attempt at resisted arrest, which culminated in the death of L1, also frustrated a deal conducted by the leader in that city, regarding the trafficking of narcotics in Pará territory, as well as the understanding of the degree of the danger and the criminal's real situation, previously identified by the intelligence agencies, prevented the operation from offering real risks to the civil police officers involved. Likewise, the news of L1's death disseminated, the bodies immediately identified the assumption of L2 as the leader of the CCA.

Even though the faction lost relative strength inside and outside prison with the death of L1, it was found that it even temporarily ally itself with the Comando Vermelho, due to the return of its more expressive regional leadership. However, war broke out between Comando Vermelho and the PCC at the national level, and, as CCA members refused to attack members of the PCC in measures to expand the dominion of the Comando Vermelho in the State (Reis Netto \& Chagas, 2019 c), the faction started to figure as a direct target of the latter faction, as identified by the state subsystem.

Immediately after, the intelligence agencies verified a salve (general communication issued by criminal factions regarding a certain event or order between the members) (Manso \& Dias, 2018), regarding the need to transfer inmates and overcoming the alleged oppression by rival inmates belonging to the Comando Vermelho. It evidenced the return of the alliance between PCC and CCA. And, noting that conflicts occurred in other states of the federation (Manso \& Dias, 2018) this had a high possibility of occurrence in Pará, through knowledge disseminated by intelligence agencies, on 10.16.2016 an operation was triggered in the penitentiaries of the complex of Americano Prison, for the separation of factions into different blocks, before territorial confrontations for the control of local networks (whose main nodes were in prison) before they could appear in the open. In this sense, it should be noted that the integrated action between the security agencies, after knowledge produced by the intelligence agencies, may have saved the penitentiary system from a real collapse.

Including, the crossing of open data made it possible to identify a lawyer from Pará who acted on behalf of the PCC, which, in turn, enabled the verification of several requests for transfer of members of the latter, bringing new facts and territorial agents to the knowledge of public security agencies. The members of the CCA, in turn, were also housed in the same prisons occupied by factions of the PCC, given the alliance between the organizations, according to the population distribution pointed out by Reis Netto and Chagas (2019a), who, on the one hand, avoided a massive confrontation among the groups, however, on the other hand, as pointed out by the intelligence agencies, it ended up bringing together and strengthening the internal associative ties between the factions, even so a, less serious result. 
And even trapped in a context of war, the participation of members of the faction in attempt on the life of the Director of Penitentiary Recovery Center of Altamira - CRRALT on 22/02/2017 was identified. At the same time, the faction organized a strong strike within the same establishment. The collection of sensitive knowledge on the subject was crucial to the transfer of L4, the local leader, to federal prisons and, also, to the discovery of the faction's participation in the death of two prison officers who played a direct role in confronting the State, as well as, in the frustration of other attacks intended by it.

At this point, the intelligence agencies had identified 43 (forty-three) persons deprived of liberty linked to the Comando Clase A, and also another 136 (one hundred and thirty-six) linked to the PCC, in the Americano complex alone, in March 2017. The identification of the factions in question, in a period of declared war between criminal organizations, certainly represented a guarantee for the lives of the inmates themselves, preventing them from being displaced or transferred to areas that represented real risks to their the lives and lives of civil and military civil servants responsible for its custody.

In short, the knowledge produced by intelligence agencies in advising the various managers of public security agencies and, ultimately, the Pará state government itself, made it possible to make more precise strategic choices, in the sense of:

A) Identify CCA leaders and factions, in order to monitor their illicit actions and seek re-socialization measures, when possible, or even formulating requests for their transfer to establishments submitted to the Differentiated Disciplinary Regime, as the case may be.

B) Identify areas inside and outside the prison, linked to the CCA and the PCC, for taking strategic actions aimed at the cessation or reduction of criminal conduct.

C) Anticipate actions to confront the State, effectively mobilizing and using force in a proportionate and adequate manner to frustrate criminal actions, thus avoiding unnecessary or inappropriate expenditure of energy in territorial disputes with criminal organizations.

D) Understand the international, regional and local context of criminal activities (especially drug trafficking), allowing for better action by state security forces (bound to the limits of the legal territory and cooperation with other federal and other state forces) and the visualization of the locations that represent nodes in these networks.

E) Preserve the lives of public agents possibly targeted by criminal organizations or potentially reachable by their measures of direct confrontation with the State, guaranteeing the safety of institutions and the lives of civil and military servants in Pará.

F) Identify factions of allied and rival groups, to apply re-socializing measures (when possible) and to avoid their transit in places or establishments that pose risks to them and to other civil and military servants involved in their custody.

From the facts reported above, extracted from the analysis of the content of historically collected sources and data, it is observed that, by enshrining the purposes of the National Doctrine of Intelligence in Public Security relating to "supporting the integrated strategic planning of the Public Security system and the elaboration of specific plans for the various organizations that comprise it " and to "advise, with relevant information, prevention and repression operations, in the interest of Public Security" (Brasil, 2014, p. 13), the State's intelligence agencies they immediately provided means to rebalance the power relations between the State, society and criminal groups, in an equation influenced by international, regional and local variables, as well as historical, economic, political and social variables.

However, although this rebalancing cannot be materially measured, it is enough to think about the quantity of crimes avoided and lives preserved, to certainly conclude about the importance of the activity carried out by the intelligence agencies, in favor of the performance of the agencies of security in facing organized crime. 


\section{Final Considerations}

The present study aimed to verify, through the historical analysis of the emergence and development of a criminal faction in the state of Pará, how the intelligence activity was able to advise the decision-making process of public security institutions, in a way to generate a balance of forces favorable to the latter, an issue that was duly proven in the content of the analysis results topic.

In addition to subsidizing public managers with knowledge appropriate to the decision-making process in confronting the various criminal organizations that currently coexist in the Pará penitentiary system, in particular, the faction studied here, the Comando Clase A (CCA -331), the component agencies of the subsystem of intelligence in the state of Pará were responsible for the frustration of measures to confront the state directly, preventing damage to public coffers and, eventually, unjust attacks on civil and military public servants and, ultimately, on Pará society itself.

In a set of relationships influenced by global, regional and local factors (since international drug trafficking, the main financial source of organizations has this characteristic that transcends legal limits), obtaining data capable of generating sensitive knowledge is unquestionably crucial to the preservation of order and public safety, so that, in terms of strategic management, the role of intelligence should be extolled as an indispensable function of the Democratic State of Law.

This time, as a suggestion for continuity, an academic and strategic expansion of the debates around the intelligence activity, limits and forms of action is recommended, obviously, always under careful preservation of its own methods and specialized agents, after all, the activity in question is so fundamental and strategic that, currently, it is already adopted by private entities around the world and, without a shadow of a doubt, by criminal organizations that are antagonistic to the State and democracy.

\section{References}

Amorim, C (2015). CV-PCC: a irmandade do crime. Record.

Antunes, P. C. B. (2001). SNI \& ABIN: Uma leitura da atuação dos serviços secretos ao longo do Século XX. FGV

Alvez-Mazzotti, A. J. (2006). Usos e Abusos do Estudo de Caso. Cadernos de Pesquisa, 36 (129), p. 637-651.

Brasil (1988). Constituição da República Federativa do Brasil de 1988. Governo Federal.

Brasil (2014). Doutrina Nacional de Inteligência em Segurança Pública. Governo Federal.

Brasil (1999). Lei n. 9.883 de 7 de dezembro de 1999. Governo Federal.

Campo Grande News (2016). Morto em confronto com a polícia respondia por 50 homicídios no Pará. https://www.campograndenews.com.br/cidades/capital/morto-emconfronto-com-a-policia-respondia-por-50-homicidios-no-para.

Cepik, M. A. C (2001). Serviços de inteligência: agilidade e transparência como dilemas de institucionalização. IUPERJ.

Estado do Pará (2011). Lei n. 7.584, de 29 de dezembro de 2011. Governo do Estado.

Farias, A. C. F, (2017). Atividade de Inteligência: O Ciclo da Produção do Conhecimento. Edições do autor.

Fernandes, B. G. (2014). Curso de direito constitucional. Jus Podivm.

G1 (2019). 26 dos 62 detentos mortos em massacre de Altamira eram presos provisórios. https://g1.globo.com/pa/para/noticia/2019/08/03/25-dos-58-detentosmortosem-massacre-de-altamira-eram-presos-provisorios.ghtml.

G1 (2015). Imagens mostram morte de mulheres após tentativa de fuga no PA. http://g1.globo.com/pa/para/noticia/2015/11/imagens-mostram-morte-demulheres-apostentativa-de-fuga-no-pa.html.

G1 Pará (2016). Roubos aumentam quase 80\% no período de um ano em Altamira, PA. http://g1.globo.com/pa/para/noticia/2016/08/roubos-aumentam-quase80-no-periodo-de-umano-em-altamira-pa.html

G1 (2016). Tentativa de resgate em presidio deixa um morto, em Santa Izabel, PA. http://g1.globo.com/pa/para/noticia/2016/03/tentativa-de-resgate-empresidio-deixaum-morto-em-santa-isabel-pa.html.

Gonçalves, J. B. (2009). Atividade de Inteligência e legislação correlata. Impetus. 
Research, Society and Development, v. 10, n. 9, e36510918285, 2021

(CC BY 4.0) | ISSN 2525-3409 | DOI: http://dx.doi.org/10.33448/rsd-v10i9.18285

Keegan, J. (2006). Inteligência na guerra: conhecimento do inimigo, de Napoleão à Al-Qaeda. Companhia das Letras.

Lakatos, E. M., \& Marconi, M. A. (2003). Fundamentos de Metodologia Científica. Atlas.

Manso, B. P., \& Dias, C. N. (2018). A guerra: Ascenção do PCC e o mundo do crime no Brasil. Todavia.

Miranda, W. D. (2018). O controle parlamentar da atividade de inteligência no Brasil: um estudo sobre a produção legislativa da CCAI e da CREDN entre os anos de 2003 a 2010. PPGDTU/UFPA.

Nascimento, D. M., Reis Netto, R. M., \& Miranda, W. D. (2018). Controle de legalidade do ato jurídico-administrativo praticado na atividade de inteligência: o caso do Estado Democrático de Direito brasileiro. Pensar - Revista de Ciências Jurídicas, (23) 04, 1-17.

Pereira, A. S., Shitsuka, D. M., Parreira, F. J., \& Shitsuka, R. (2018). Metodologia da pesquisa científica. UFSM.

Protásio, G. (2011). Gestão da Segurança Pública no Brasil: vetores de análise e dimensões de gestão de Projetos Interorganizacionais de longo prazo, para a elaboração de indicadores estratégicos. In: Brasil. Ministério da Justiça. Secretaria Nacional de Segurança Pública. Segurança, Justiça e Cidadania, (p. 151176). Brasília: Governo Federal.

Raffestin, C. (1993). Por uma Geografia do poder. Editora Ática.

Reis, J. F. G., \& Souza, J. L. C. (2016). Grandes projetos na Amazônia: A hidrelétrica de Belo Monte e seus efeitos na segurança pública. Dilemas: Revista de Estudos de Conflito e Controle Social, 9 (2), 215-230.

Reis Netto, R. M., \& Chagas, C. A. N. (2019a). Além das grades: um estudo de caso sobre as estratégias utilizadas para integração dos presídios às redes territoriais externas do tráfico de drogas. Geosul, 34 (73), 149-174.

Reis Netto, R. M., \& Chagas, C. A. N. (2019b). Associação interna como forma de integração dos presídios às redes externas do tráfico: a percepção dos agentes territoriais da segurança pública no estado do Pará. Rev. direito GV, 15 (2), 1-19.

Reis Netto, R. M., \& Chagas, C. A. N. (2019c). A percepção de agentes da segurança pública a respeito do enfrentamento ao poder público como estratégia de integração dos presídios às redes externas do tráfico de drogas. In: Trindade, C. M. (org). Segurança Pública: ética e cidadania. CRV.

Reis Netto, R. M., \& Chagas, C. A. N. (2018). Estratégias e Mediatos Utilizados pelo Tráfico de Drogas para Integração dos Presídios às Redes Territoriais Externas: uma Revisão da Literatura. Opinião Jurídica, 16 (23), 110-139.

Reis Netto, R. M., Miranda, W. D., Gomes, H. W. A. J., \& Chagas, C. A. N. (2018). A legalidade do ato praticado na atividade de inteligência: perspectivas de validade perante o ordenamento jurídico atual. In: Miranda, W. D., Reis Netto, R. M., Santos, L. R. L. Atividade de inteligência e segurança pública: O Brasil e as trincheiras do século XXI Ananindeua/PA: Edições dos Autores 